\title{
Inmunohistochemical Evaluation of Estrogen Receptors Alpha and Beta in Normal Inferior Turbinate Mucosa
}

\author{
Evaluación Inmunohistoquímica de los Receptores de Estrógenos Alfa y Beta \\ en la Mucosa Normal de Concha Nasal Inferior
}

\author{
"Ieda Millas; *"Bianca Maria Liquidato; "José Eduardo Lutaif Dolci; **José Rafael Macéa; \\ **:José Humberto Tavares Guerreiro Fregnani \& ***:Lenira Rocha Meceles
}

MILLAS, I.; LIQUIDATO, B. M.; DOLCI, J. E. L.; MACÉA, J. R.; FREGNANI, J. H. T. G. \& MECELES, L. R. Inmunohistochemical evaluation of estrogen receptors alpha and beta in normal inferior turbinate mucosa. Int. J. Morphol., 28(1):143-150, 2010.

SUMMARY: It has been postulated that the nasal mucosa, like other human tissues, is affected by a complex interactive network of neuropeptides, cytokines, allergic and inflammatory mediators and hormones such as estrogen, in which associations between symptoms (e.g. nasal stuffiness and coryza) and hormonal variations deriving from pregnancy, use of hormonal contraceptives and menstrual cycle phases are observed. The objective is evaluating the presence of specific estrogen receptors (types alpha and beta) in inferior turbinate mucosa in healthy subjects without nasal symptoms. Samples of nasal inferior turbinate were removed from patients undergoing aesthetic nasal surgery, and analyzed using hematoxylin-eosin staining, followed by immunohistochemical preparations on paraffin-embedded sections from the material sample, to detect estrogen receptors alpha and beta. Positive immunohistochemical reactions for both beta and alpha receptors were found in various regions of the inferior nasal turbinate. In conclusion both alpha and beta receptors were found, though the expression of beta was greater and more intense in the anterior portion of the inferior turbinate. No difference was found between male and female patients regarding the intensity of expression of receptors in the inferior turbinate.

KEY WORDS: Rhinitis; Estrogen receptors; Estrogens; Nasal mucosa; Hormones, Immunohistochemistry.

\section{INTRODUCTION}

Rhinitis is defined as a nasal mucosal inflammation, and is mainly characterized by symptoms of rhinorrhea and/ or nasal congestion. Chronic nasal non-allergic inflammation can be called non-allergic rhinitis. The incidence of nonallergic rhinitis ranges from 17 to $52 \%$ in the literature, and 58 to $74 \%$ of such cases occur in women (Settipane \& Lieberman, 2001; Bachert, 2004; Garay, 2004).

Estrogen-induced rhinitis has been cited in some nonallergic rhinitis classifications. According to Settipane, it can be classified as metabolic, non-inflammatory and nonallergic. Nevertheless, Garay, classified the rhinitis associated with the use of hormonal contraceptives as a druginduced rhinitis type.

It has been postulated that the nasal mucosa, like other human tissues, is affected by a complex interactive network of neuropeptides, allergic and inflammatory mediators and hormones. Thus, associations between hormonal changes and nasal conditions have been described in the literature based on clinical trials, thus showing connections between symptoms such as nasal stuffiness and coryza and hormonal variations in pregnancy, use of contraceptives and menstrual cycle phases (Philpott et al., 2004).

Estrogen is a steroidal hormone and is associated with female reproduction, but it has actions in both men and women. It is synthesized in ovaries and testicles, but it is also found in peripheral tissues. The effects of estrogen on a significant number of tissue types not associated with reproduction (such as bones and the cardiovascular, gastrointestinal, immunological and central nervous system) have been studied recently (Paech, 1997; Pavao \& Traish, 2001). A large number of clinical conditions are associated

* Otorhinolaryngology Department of Santa Casa de São Paulo, School of Medical Sciences, São Paulo, Brazil.

** Morphology Department of Santa Casa de São Paulo, School of Medical, São Paulo, Brazil.

*** Pathology Department of Santa Casa de São Paulo, School of Medical Sciences, São Paulo, Brazil. 
with changes in estrogen production or hormonal cell response, such as osteoporosis, atherosclerosis and breast, endometrial and prostate cancer (Enmark \& Gustafson, 1999). In the central nervous system, estrogen is considered to be a neuroprotection agent against cerebral ischemia (Cimarosti, 2005). Moreover, this hormone is also known to have a role in modulating neurogenic inflammatory reactions (Bjorling \& Wang, 2001). In the oral mucosa, estrogen improves the activity of salivary secretion (Leimola-Virtanen, 2000, Välimaa et al., 2004). In conjunctiva, estrogen can induce changes in allergic responses and maturation of goblet cells and epithelium (Fuchsjäger-Mayrl, 2002). In the lungs, estrogen can increase the reactivity and vascular permeability of the bronchial mucosa (Degano, 1998) and can also trigger an inflammatory response mediated by mast cells (Zhao et al., 2001). However, few studies on the physiology of the assumed action of estrogen on the nasal mucosa exist.

For estrogen to perform its various functions of cell metabolic regulation in different tissues, the presence of specific protein intranuclear receptors is required. In 1958, Elwood Jensen discovered the first estrogen receptor, which was cloned in 1986 and named the alpha receptor (Green et al., 1986) Ten years later, in 1996, a second estrogen receptor was discovered and named beta (Kuiper et al., 1997). Subsequently, several studies on these two isoforms of estrogen receptors have shown that they are highly specific in humans and enable selective hormonal action on different tissues (Peach et al.; Mosselman et al., 1996; Kuiper et al.).

Among the authors describing an association between nasal symptoms and blood estrogen levels, Philpott et al., in 2004, observed increased nasal obstruction in women at times of high blood estrogen levels, compared with a control group, through using acoustic rhinometry, anterior rhinomanometry and measurements of peak inspiratory nasal flow. Navarrete-Palacios et al. (2003), used cytological analysis to compare nasal and vaginal smears from different phases of the menstrual cycle and observed that both types of smear showed the same characteristics, thus suggesting that cell turnover in the nasal epithelium is influenced by hormonal state. Nappi et al. (2003), observed reduced number of goblet cells and seromucinous glands in the lamina propria of the nasal mucosa in menopausal women, compared with controls of reproductive age. Caruso et al. (2003), compared nasal and vaginal mucosal smears from menopausal women with and without hormone replacement therapy and observed that both the nasal and the vaginal epithelium showed the same cytological characteristics in women undergoing hormone replacement therapy. Haeggström et al. (2000), found a connection between high blood estrogen levels and nasal mucosal reactivity in healthy fertile women during the menstrual cycle.
Other studies have revealed that in the nasal mucosa, estrogen may trigger morphological and histological changes that vary in intensity according to the type of tissue and the presence of estrogen receptors. These abnormalities consist of epithelial metaplasia, lymphocyte infiltration, increased vascularity and glandular hyperactivity (Toppozada et al., 1984). Toppozada et al. (1981; 1984) contributed through studies on humans that demonstrated morphological and histochemical changes to the nasal mucosa that were associated with estrogen. In a experimental study on guinea pigs, Zhao et al. (1994), noted histological abnormalities such as thickening of epithelial layers, edema of the corium, hyperplasia of glands and increased density of cilia in the mucosa of guinea pigs receiving estrogen compared with the control group.

Bowser \& Riederer (2001) used an immunohistochemical method to analyze the nasal mucosa and detected estrogen receptors (unspecific) in the cellular cytoplasm of seromucinous glands and glandular ducts in the inferior turbinate mucosa of pregnant women and also in the nasal mucosa of women taking hormonal contraceptives who presented symptoms of rhinitis. Balbani (2001) also detected estrogen receptors through immunohistochemical analysis on cytoplasm of seromucinous glands of the lamina propria of the inferior turbinate in male subjects with chronic rhinopathy. Shirasaki et al. (2004), used an immunohistochemical method to detect the presence of alpha receptors in the nuclei of interstitial cells (mainly mast cells) of the nasal mucosa, and beta receptor-specific nuclear staining was seen in seromucinous glands of the lamina propria of the inferior turbinate mucosa.

In 2008, Philpott et al. used the immunohistochemical method on paraffin-embedded material to investigate estrogen receptors alpha and beta and progesterone receptors in biopsy samples from the mucosa of the inferior nasal turbinate of 25 patients with rhinitis who underwent otorhinolaryngological surgical procedures. Among these patients, 16 were male. The age range was from 18 to 68 years. None of the biopsies showed positive reactions for estrogen receptor alpha or for progesterone receptors. Estrogen receptor beta was present in 24 out of the 25 samples, in the cells of the glandular epithelium of the lamina propria and in cells of the lamina propria and venules. There were no statistically significant differences between the groups of men and women, atopic and non-atopic individuals or smokers and nonsmokers.

The role of the inferior turbinate mucosa is crucial in respiratory physiology because of the anatomy of the inferior nasal turbinate, which presents a large surface in the nasal cavity. A significant number of nasal conditions, such as rhinitis and rhinosinusitis, derive from dysfunctions of 
this mucosa. In addition, because of the large number of seromucinous glands, this mucosa plays an important role in the production of significant volumes of nasal secretion. Thus, because of the great importance of the inferior nasal turbinate mucosa within nasal physiology, it was chosen for evaluations on estrogen receptors.

Therefore, because of numerous studies showing an association between rhinitis and estrogen, along with the postulated presence of hormonal receptors in the nasal mucosa, the present study aimed to evaluate the presence of specific estrogen receptors (alpha and beta) in the inferior turbinate of asymptomatic patients, in order to better characterize the influence of hormones on physiopathological nasal processes that are still not fully understood in clinical practice.

\section{MATERIAL AND METHOD}

The current study was approved by the Ethics Committee for Human Research of Irmandade da Santa Casa de Misericórdia de São Paulo (under project number 173/ 04) and it was carried out in accordance with the ethical norms of the aforementioned institution. Signed consent forms were obtained from all patients. For this prospective study, samples of inferior turbinate mucosa were collected from patients undergoing esthetic nasal surgery who presented no other functional complaints. The samples underwent anatomopathological analysis using the hematoxylin-eosin staining technique, followed by immunohistochemical staining for detection of the presence of estrogen receptors.

The following criteria were applied:

1. Inclusion criteria: the subjects had to be of reproductive age, undergoing esthetic nasal surgery (rhinoplasty) without any other symptoms associated with nasal function;

2. Exclusion criteria: presence of rhinopathy and/or rhinosinusitis, presence of allergic diseases, use of hormonal contraceptives, use of hormonal therapy, presence of hormonal disorders, use of spray medications, past history of nasal or reproductive cancer.

Ten patients were selected (Table I), of whom six were male and four were female. The patients' age range was from 19 to 60 years old; the 60 -year-old patient was male.

A small sample was removed from the inferior nasal turbinate mucosa (randomly, right or left) during the surgical intervention. It was linearly sectioned (anterior-posterior) and divided into anterior (corresponding to the anterior third portion), middle (corresponding to the middle third portion)
Table I. Age and sex distribution of the study subjects.

\begin{tabular}{lcccc}
\hline Cases & Name & Registration & Age & Sex \\
\hline 1 & S.A.S. & 964338 & 19 & $\mathrm{M}$ \\
2 & D.S.S. & 960169 & 23 & $\mathrm{~F}$ \\
3 & S.S.L.A. & 948155 & 24 & $\mathrm{~F}$ \\
4 & M.F.M. & 112604 & 60 & $\mathrm{M}$ \\
5 & A.A.R.R. & 988977 & 31 & $\mathrm{~F}$ \\
6 & J.V.S. & 940306 & 45 & $\mathrm{M}$ \\
7 & R.Z. & 964780 & 42 & $\mathrm{M}$ \\
8 & A.A.P. & 981317 & 26 & $\mathrm{~F}$ \\
9 & K.S.L. & 1005325 & 28 & $\mathrm{~F}$ \\
10 & C.F.L. & 997280 & 29 & $\mathrm{~F}$ \\
\hline
\end{tabular}

and posterior (corresponding to the posterior third portion). This linear fragment, which included the whole length of the medial face of the turbinate, was removed using turbinectomy scissors without straining or previous infiltration. Each fragment was approximately $0.5 \mathrm{~cm}$ wide and thick and its length varied according to each nasal turbinate. The material was then immersed in $10 \%$ formaldehyde, embedded in paraffin and cut into sections of $3 \mathrm{~mm}$ in thickness using a rotary microtome. The sections underwent hematoxylin and eosin (HE) staining and histological analysis.

To investigate estrogen receptors alpha and beta, the paraffin blocks were sectioned at a thickness of $4 \mathrm{~mm}$, using 3-aminopropyltriethoxysilane.

The immune-peroxidase technique (in accordance with previous descriptions by Kuiper et al., Paech et al.; Leimola-Virtanen et al., 2000; Zafrani et al., 2000; Pavao et al.) was applied using the standard methodology for immunohistochemistry. The analysis was developed at the Laboratory of the Pathology and Morphology Departments of the School of Medical Sciences of Santa Casa de São Paulo, Brazil.

To detect estrogen receptor alpha, primary antibodies against it were applied, consisting of monoclonal mouse antihuman ERa antibodies, 1D5 clone, code \# M 7047 (Dako Cytomation). Estrogen receptor beta was detected by means of monoclonal mouse anti-human ERb antibodies, MCA 1974ST \# 070105 (Serotec - Immunological Excellence). Both types of antibodies were used for reactions in paraffinembedded tissues.

The positive controls for estrogen receptors alpha and beta were obtained from breast carcinoma tissue, and these underwent analysis simultaneously with the nasal tissue 
under study. Both controls showed dark-brown granular staining in the cellular compartment where the antigenprimary antibody binding had occurred. The slices from the inferior turbinate mucosa were analyzed by means of optical microscopy and were randomly photographed. Photographs of three areas of each case were analyzed for the presence of dark brown granular areas and similarity with the matched positive controls, as well as for their distribution in the cytoplasm of the glandular epithelium cells. The histological and immunohistochemical analyses were performed by two histologists, who were unaware of the patient's gender, age or background. Few cases required a meeting to reach a diagnostic consensus. The assessment of histopathological patterns was conducted semi-quantitatively, using an immunoreactivity score (Stierer et al., 1993). The percentage of glandular epithelium cells that presented immunohistochemical staining was ranked on a scale from 0 to 4 points, such that 0 corresponded to lack of staining, 1 to
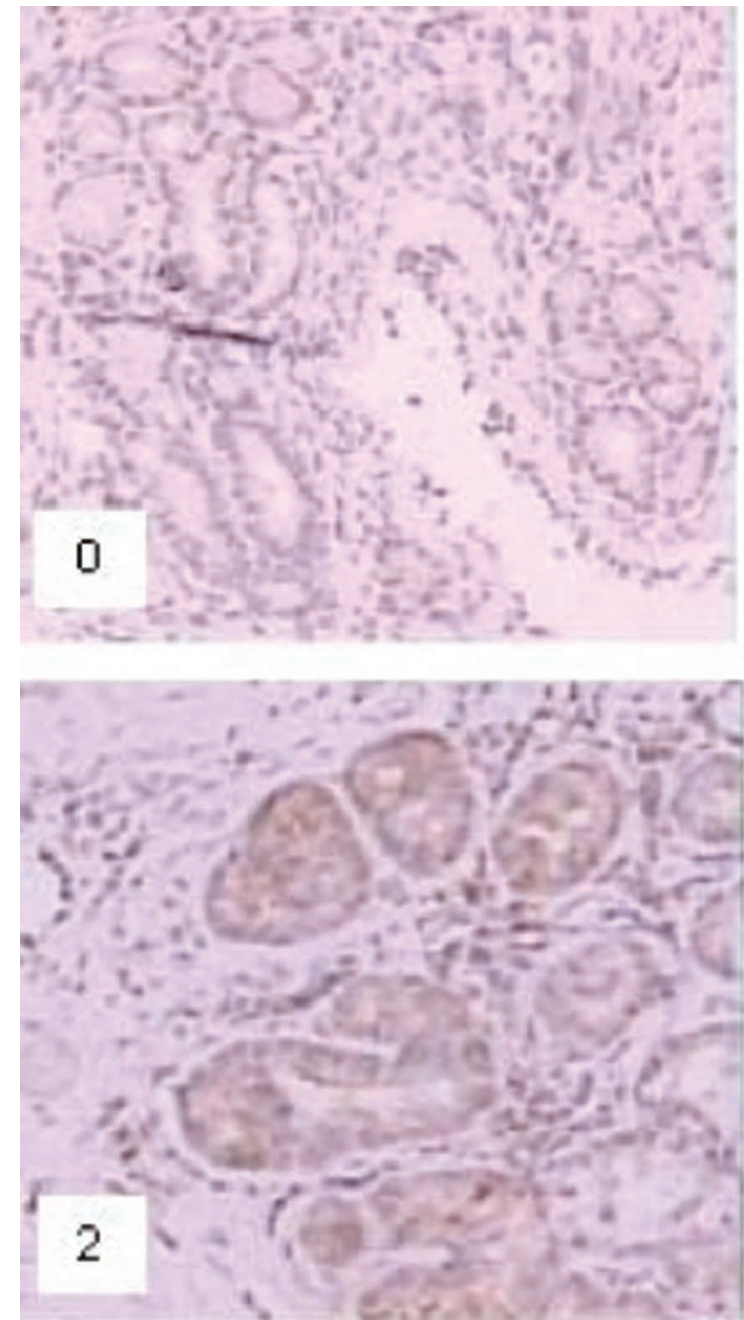

less than $10 \%$ staining, 2 to $11-50 \%, 3$ to $51-80 \%$ and 4 to over $80 \%$. Furthermore, the staining intensity, classified as 0 (lack of staining), 1 (weak), 2 (moderate) or 3 (intense), was also taken into consideration (Fig. 1). The cases studied were thus given a final ranking between 0 and 7 , such that $0-1$ represented lack of staining, 2-3 weak staining, 4-5 moderate staining and 6-7 intense staining. Thus, the cases were properly classified, ranging from 0 to 3 (Tables II and III).

Next, the intensity values of the median expression of estrogen receptors alpha and beta were statistically analyzed by means of the non-parametric Friedman Test, in relation to the sample location within the inferior turbinate (Table IV). The nonparametric Mann-Whitney test was used for statistical analysis on the median values of the expression intensity of estrogen receptors alpha and beta, in relation to gender and location within the inferior turbinate mucosa (Table V).
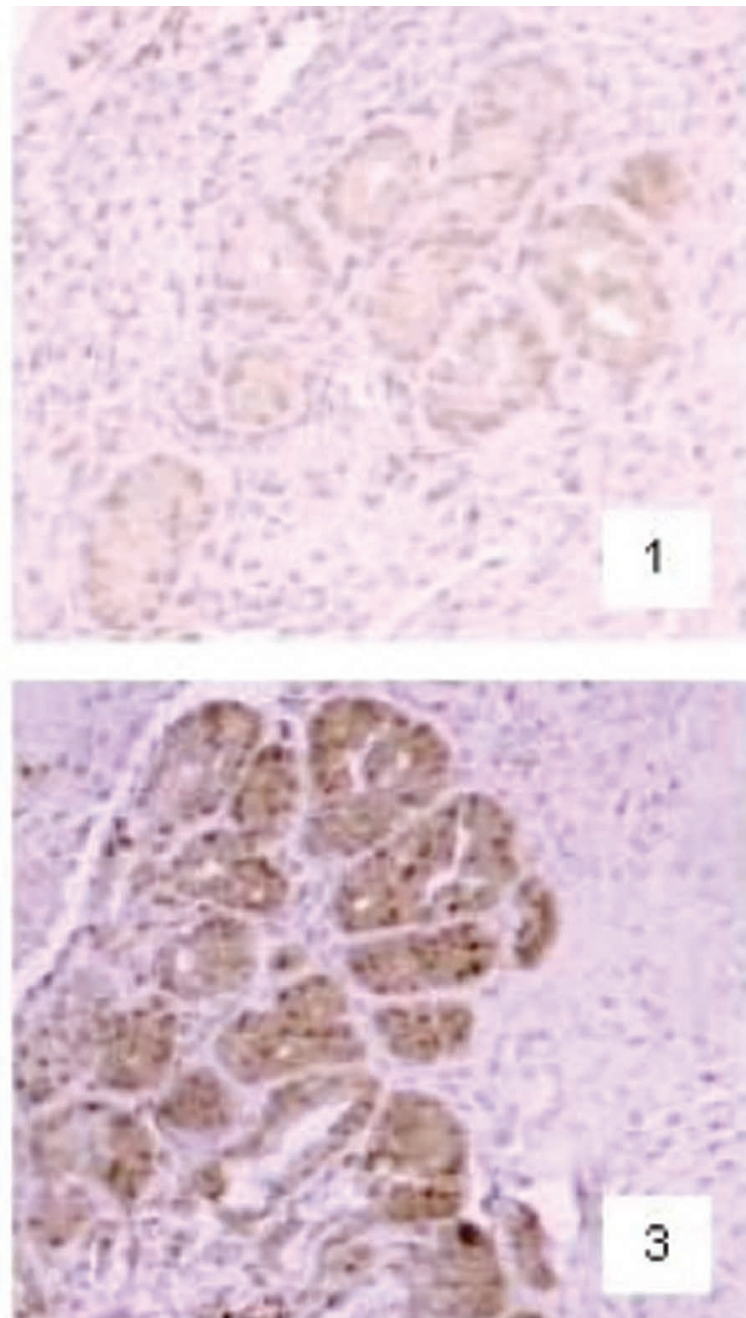

Fig. 1. Four different histological sections through the inferior turbinate mucosa showing: 0- lack of staining; 1- weak staining; 2- moderate staining; and 3-intense positive staining from the immunohistochemical reaction for estrogen receptors in glandular epithelial cells of the lamina propria (200X) 
Table II. Estrogen receptor beta expression in different regions of the inferior turbinate. $0=$ lack of staining; $1=$ weak staining; $2=$ moderate staining; 3 = intense staining.

\begin{tabular}{lccc}
\hline & Anterior & Middle & Posterior \\
\hline Case 1 & 3 & 3 & 3 \\
Case 2 & 2 & 1 & 2 \\
Case 3 & 2 & 1 & 1 \\
Case 4 & 3 & 2 & 2 \\
Case 5 & 3 & 2 & 2 \\
Case 6 & 1 & 1 & 1 \\
Case 7 & 3 & 2 & 2 \\
Case 8 & 2 & 2 & 1 \\
Case 9 & 2 & 3 & 2 \\
Case 10 & 3 & 3 & 2 \\
\hline
\end{tabular}

Table III. Estrogen receptor alpha expression in different regions of the inferior turbinate. $0=$ lack of staining; 1 = weak staining; 2 $=$ moderate staining; 3 = intense staining.

\begin{tabular}{lccc}
\hline & Anterior & Middle & Posterior \\
\hline Case 1 & 2 & 3 & 2 \\
Case 2 & 1 & 1 & 0 \\
Case 3 & 1 & 1 & 1 \\
Case 4 & 2 & 2 & 2 \\
Case 5 & 1 & 1 & 1 \\
Case 6 & 1 & 1 & 1 \\
Case 7 & 3 & 1 & 2 \\
Case 8 & 1 & 1 & 2 \\
Case 9 & 1 & 1 & 2 \\
Case 10 & 1 & 0 & 2 \\
\hline
\end{tabular}

\section{RESULTS}

For the 10 selected patients (Table I) (six males and four females), the age range was from 19 to 60 years, the mean age was 32.7 years and the median age was 39.5 years.

Positive immunohistochemical reactions for both alpha and beta receptors were found in all regions of the inferior turbinate, in the cytoplasm of the lamina propria of the glandular cells.

The quantitative and semi-quantitative evaluation for detecting the presence of estrogen receptors alpha and beta was classified 0-3, as previously described (Tables II and III).

Median values for the expression intensity of staining
Table IV. Median values of expression intensity of estrogen receptors alpha and beta according to their location in the inferior turbinate mucosa. (*) Nonparametric Friedman test.

\begin{tabular}{lccc}
\hline Receptor & $\begin{array}{c}\text { Location in } \\
\text { the inferior } \\
\text { turbinate }\end{array}$ & $\begin{array}{c}\text { Expression } \\
\text { intensity } \\
\text { (median) }\end{array}$ & $\begin{array}{c}\text { P value } \\
(*)\end{array}$ \\
\hline Beta & Anterior & 2.5 & 0.030 \\
& Middle & 2.0 & \\
\multirow{3}{*}{ Alpha } & Posterior & 2.0 & \\
& Anterior & 1.0 & 0.638 \\
& Middle & 1.0 & \\
& Posterior & 2.0 & \\
\hline
\end{tabular}

Table V. Median values of expression intensity of estrogen receptors alpha and beta according to gender and location in the inferior turbinate mucosa. (*) Nonparametric Mann-Whitney test.

\begin{tabular}{lcccc}
\hline Receptor & $\begin{array}{c}\text { Location in } \\
\text { the inferior } \\
\text { turbinate }\end{array}$ & $\begin{array}{c}\text { Women } \\
(\mathbf{n}=6)\end{array}$ & $\begin{array}{c}\text { Men } \\
(\mathbf{n}=4)\end{array}$ & $\begin{array}{c}\text { P value } \\
(*)\end{array}$ \\
\hline Beta & Anterior & 2.0 & 3.0 & 0.610 \\
& Middle & 2.0 & 2.0 & 1.000 \\
\multirow{3}{*}{ Alpha } & Posterior & 2.0 & 2.0 & 0.610 \\
& Anterior & 1.0 & 2.0 & 0.067 \\
& Middle & 1.0 & 1.5 & 0.171 \\
& Posterior & 1.5 & 2.0 & 0.476 \\
\hline
\end{tabular}

for alpha and beta receptors in different regions of the inferior turbinate were calculated using the nonparametric Friedman Test. A statistically significant difference in the expression intensity of beta receptors in the inferior turbinate was found such that the expression was more intense in the anterior portion (Table IV).

Median values for the expression intensity of estrogen receptors alpha and beta, according to gender and location in the inferior turbinate mucosa, were calculated by means of the nonparametric Mann-Whitney test. This showed that there was no statistically significant difference between men and women regarding the expression intensity of the receptors located in the inferior turbinate (Table V). 


\section{DISCUSSION}

The current study showed a statistically significant difference in the expression intensity of beta receptors in the inferior turbinate, such that this was greater in the anterior portion. According to the literature reviewed, the two isoforms of estrogen receptors seem to trigger the same response, albeit the different concentrations in certain organs and tissues account for selective action of estrogen. Alpha receptors seem to be found more in organs associated with reproduction, whereas beta receptors present more significant concentrations in tissues such as the central nervous system, genitourinary tract, gastrointestinal tract, oral mucosa, salivary glands and lungs (Kuiper et al.). The greater expression of beta receptors in the nasal mucosa is compatible with the previous papers in the literature cited here.

With the exception of the studies by Ellegård \& Karlsson, 1994; Ellegård, 2003; Paulsson et al., 2007 all the remaining authors cited here advocated correlations between blood estrogen levels and changes in nasal physiology. The importance of this finding lies not only in better comprehension of the factors implicated in nasal physiology, but also in the elucidation of diseases described in the literature that remain poorly understood, such as rhinitis during pregnancy and rhinitis associated with the use of oral hormonal contraceptives.

Our study also showed that there was no statistically significant difference between men and women, regarding the expression intensity of the receptors located in the inferior turbinate. This proves that, like in other organs not associated with reproduction, estrogen may perform specific functions in both men and women, since this hormone and its respective receptors are present in both genders, albeit distinctly in quantity and distribution in different organs and tissues.

The immunohistochemical staining of cytoplasm can be questioned regarding its nonspecificity for hormonal receptors, since this staining is usually observed in cell nuclei where these receptors bind to cell DNA. However, it is known that estrogen receptors are dispersed throughout the cytoplasm and that their migration to cell nuclei only occurs after connecting with the hormone. Furthermore, some authors underline the importance of the location of these receptors within the cytoplasm. For instance, Kalesnykas et al. (2005), pointed out that in the cell cytoplasm, estrogen receptors can also be associated with the Htsp 90 protein, which is responsible for hormone-receptor complex binding with DNA. It is also possible that these receptors are indirectly involved with genetic transcription through interactions with proteins present in the cytoplasm.

The methodology used in the present study did not reveal the intracellular location of these receptors, which could be connected with the cell membrane, thereby modulating intracellular effects through calcium channels. Further studies are needed in order to define such locations. Nevertheless, it is already important to note that these receptors (mainly the beta type) were found exclusively in cells of seromucinous glands of the lamina propria.

Evidently, more studies with greater numbers of samples are needed in order to define the role of these receptors in the nasal mucosa. If the action of estrogen through its receptors on the nasal mucosa is proven, for instance with regard to secretory activity, a pharmacological approach towards regulating its glandular expression will be possible, thereby benefiting both patients with nasal dryness and those with rhinorrhea.

The current study can be considered to be a pilot study and it may open up new possibilities for better comprehension of the complex physiology of the nasal mucosa and its interaction with other substances, such as estrogen hormones.

In conclusion, the present study showed the presence of alpha and beta receptors, with higher beta expression and higher intensity in the anterior portion of the inferior turbinate. No difference between men and women was found in relation to the intensity of receptor expression in the inferior turbinate.

\section{ACKNOWLEDGMENT}

We are grateful to the Support Center for Scientific Publications of Santa Casa de São Paulo School of Medical Sciences for editorial assistance. 
MILlAS, I.; LIQUIDATO, B. M.; DOLCI, J. E. L.; MACÉA, J. R.; FREGNANI, J. H. T. G. \& MECELES, L. R. Evaluacióninmunohistoquímica de los receptores de estrógenos alfa y beta en la mucosa normal de concha nasal inferior. Int. J. Morphol., 28(1):143-150, 2010.

RESUMEN: Se ha postulado que la mucosa nasal, al igual que otros tejidos humanos, se ve afectada por una compleja red interactiva de neuropéptidos, citoquinas, mediadores alérgicos e inflamatorios, y hormonas como el estrógeno, en el que las asociaciones entre los síntomas (por ejemplo, congestión nasal y catarro) y hormonales las variaciones derivadas del embarazo, se observó el uso de anticonceptivos hormonales y las fases del ciclo menstrual. El objetivo es evaluar la presencia de receptores de estrógenos específicos (tipos de alfa y beta) en la mucosa de la concha nasal inferior en sujetos sanos sin síntomas nasales. Las muestras de la concha nasal inferior fueron retirados de los pacientes sometidos a cirugía nasal estética y analizados mediante hematoxilina-eosina, seguidos de cortes de preparados de inmunohistoquímica incluídos en parafina de la muestra de material, para detectar los receptores de estrógenos alfa y beta. Las reacciones de inmunohistoquímica fueron positiva para ambos receptores alfa y beta, éstas se encuentran en diversas regiones del cornete nasal inferior. En conclusión, tanto los receptores alfa y beta se encuentran, aunque la expresión de la beta fue mayor y más intensa en la porción anterior de la concha nasal inferior. No se encontraron diferencias entre pacientes hombres y mujeres en relación con la intensidad de la expresión de los receptores en el concha nasal inferior.

PALABRAS CLAVE: Rinitis; Receptores de estrógeno; Estrógenos; Mucosa nasal; Hormonas, Immunohistoquímica.

\section{REFERENCES}

Bachert, C. Persistent rhinitis - allergic or nonallergic? Allergy, 59 Suppl. 76:11-5, 2004.

Balbani, A. P. S. Ação do estrógeno e progesterona na mucosa nasal humana: avaliação do transporte mucociliar nasal de sacarina e pesquisa de receptores hormonais através de método imunohistoquímico. (Doctorate Thesis - São Paulo University of Medicine). São Paulo, 2001.

Bjorling, D. E. \& Wang Z. Y. Estrogen and neuroinflammation. Urology, 57:40-6, 2001.

Bowser, C. \& Riederer, A. Detection of progesterone receptors in connective tissue cells of the lower nasal turbinates in women. Laryngorhinootologie, 80(4):1826, 2001.

Cimarosti, H.; Zamin, L. L.; Frozza, R.; Nassif, M.; Horn, A. P.; Tavares, A.; Netto, C. A.; Salbego, C. Estradiol protects against oxygen and glucose deprivation in rat hippocampal organotypic cultures and activates Akt and inactivates GSK-3beta. Neurochem. Res., 30(2):191-9, 2005.

Degano, B. The effect of estrogens on the permeability of the bronchial mucosa. Ann. Dermatol. Venereol, 125 Suppl 2:S21-2, 1998.

Ellegård, E. \& Karlsson, G. Nasal congestion during the menstrual cycle. Clin. Otolaryngol. Allied Sci., 19(5):400-3, 1994.
Ellegård, E. K. The etiology and management of pregnancy rhinitis. Am. J. Respir. Med., 2(6):469-75, 2003.

Fuchsjäger-Mayrl, G.; Nepp J.; Schneeberger, C.; Sator, M.; Dietrich, W.; Wedrich, A.; Huber, J. \& Tschugguel, W. Identification of estrogen and progesterone receptor mRNA expression in the conjunctiva of premenopausal women. Invest. Ophthalmol. Vis. Sci., 43(9):2841-4, 2002.

Garay, R. Mechanisms of vasomotor rhinitis. Allergy, 59 Suppl. 76:4-10, 2004.

Green, S.; Walter, P.; Kumar, V.; Krust, A.; Bornert, J. M.; Argos, P. \& Chambon, P. Human oestrogen receptor cDNA: sequence, expression and homology to v-erb-A. Nature, 320(6058):134-9, 1986.

Haeggström, A.; Östberg, B.; Stjerna, P.; Graf, P. \& Hallén, H. Nasal mucosal swelling and reactivity during a menstrual cycle. ORL. J. Otorhinolaryngol. Relat. Spec., 62:39-42, 2000.

Kalesnykas, G.; Roschier, U.; Puoliväli, J.; Wang, J. \& Miettinen R. The effect of aging on the subcellular distribution of estrogen receptor-alpha in the cholinergic neurons of transgenic and wild-type mice. Eur. J. Neurosci., 21(5):1437-42, 2005.

Kuiper, G. G.; Carlsson, B.; Grandien, K.; Enmark, E.; Häggblad, J.; Nilsson, S. \& Gustafsson, J. A. Comparison of the ligand binding specificity and transcript tissue 
distribution of estrogen receptors alpha and beta. Endocrinology, 138(3):863-70, 1997.

Leimola-Virtanen, R.; Salo, T.; Toikkanen, S.; Pulkkinen, J. \& Syrjänen, S. Expression of estrogen receptor (ER) in oral mucosa and salivary glands. Maturitas, 36(2):131-7, 2000.

Mosselman, S.; Polman, J. \& Dijkema, R. ER beta: identification and characterization of a novel human estrogen receptor. FEBS Lett., 392(1):49-53, 1996.

Nappi, C.; Di Spiezio Sardo, A.; Guerra, G.; Bifulco, G.; Testa, D. \& Di Carlo, C. Functional and morphologic evaluation of the nasal mucosa before and after hormone therapy in postmenopausal women with nasal symptoms. Fertil. Steril., 80:669-71, 2003.

Navarrete-Palacios, E.; Hudson, R.; Reyes-Guerrero, G. \& Guevara-Guzman, R. Correlation between cytological characteristics of the nasal epithelium and the menstrual cycle. Arch. Otolaryngol. Head Neck Surg., 129(4):460-3, 2003.

Paech, K.; Webb, P.; Kuiper, G. G.; Nilsson, S.; Gustafsson, J.; Kushner, P. J. \& Scanlan, T. S. Differential ligand activation of estrogen receptors ERalpha and ERbeta at AP1 sites. Science, 277(5331):1508-10, 1997.

Paulsson, B.; Gredmark, T.; Burian, P. \& Bende, M. Nasal mucosal congestion during the menstrual cycle. J. Laryngol. Otol., 111(4):337-9, 1997.

Pavao, M. \& Traish, A. M. Estrogen receptor antibodies: specificity and utility in detection, localization and analyses of estrogen receptor alpha and beta. Steroids, 66(1):1-16, 2001.

Philpott, C. M.; El-Alami, M. \& Murty, G. E. The effect of the steroid sex hormones on the nasal airway during the normal menstrual cycle. Otolaryngol. Head Neck Surg., 131(2):P187, 2004.

Philpott, C. M.; Wild, D. C.; Wolstensholme, C. R. \& Murty, G. E. The presence of ovarian hormone receptors in the nasal mucosa and their relationship to nasal symptoms. Rhinology, 46(3):221-5, 2008.

Settipane, R. A. \& Lieberman, P. Update on nonallergic rhinitis. Ann. Allergy Asthma Immunol., 86:494-507, 2001. Stierer, M.; Rosen, H.; Weber, R.; Hanak, H.; Spona, J. \& Tüchler, H. Immunohistochemical and biochemical measurement of estrogen and progesterone receptors in primary breast cancer. Correlation of histopathology and prognostic factors. Ann. Surg., 218(1):13-21, 1993.

Toppozada, H.; Michaels, L.; Toppozada, M.; El-Ghazzawi, E.; Talaat, A. \& Elwany, S. The human nasal mucosa in the menstrual cycle. A histochemical and electron microscopic study. J. Laryngol. Otol., 95(12):1237-47, 1981.

Toppozada, H.; Toppozada, M.; El-Ghazzawi, I. \& Elwany, $\mathrm{S}$. The human respiratory nasal mucosa in females using contraceptive pills. An ultramicroscopic and histochemical study. J. Laryngol. Otol., 98(1):43-51, 1984.

Toppozada, H. The human nasal mucosa in the menopause (a histochemical and electron microscopic study). $J$. Laryngol. Otol., 102(4):314-8, 1988.

Välimaa, H.; Savolainen, S.; Soukka, T.; Silvoniemi, P.; Mäkelä, S.; Kujari, H.; Gustafsson, J. A.; Laine, M. Estrogen receptor-beta is the predominant estrogen receptor subtype in human oral epithelium and salivary glands. J. Endocrinol., 180(1):55-62, 2004.

Zafrani, B,; Aubriot, M. H.; Mouret, E.; De Crémoux, P.; De Rycke, Y.; Nicolas, A.; Boudou, E.; Vincent-Salomon, A.; Magdelénat, H. \& Sastre-Garau, X. High sensitivity and specificity of immunohistochemistry for the detection of hormone receptors in breast carcinoma: comparison with biochemical determination in a prospective study of 793 cases. Histopathology, 37(6):536-45, 2000.

Zhao, X.; Dong, Z. \& Yang, Z. An experimental observation on the influence of the different levels of estradiol on the nasal mucosa. Zhonghua Er Bi Yan Hou Ke Za Zhi, 29(2):98100, 1994.

Correspondence to:

leda Millas

Otorhinolaryngology Department

Santa Casa de São Paulo

School of Medical Sciences

Rua Dr. Diogo de Faria, 1087 cj. 1009

CEP: 04037-003

São Paulo

BRAZIL

Phone: (11+55) 50823260

Fax: $(11+55) 50837330$

Email: iedamillas@uol.com.br

Received: 02-11-2009

Accepted: 28-01-2010 